\title{
Summer diet of the sable Martes zibellina in the Middle Yenisei taiga, Siberia
}

\author{
Marcin BRZEZIŃSKI
}

\begin{abstract}
Brzeziński M. 1994. Summer diet of the sable Martes zibellina in the Middle Yenisei taiga, Siberia. Acta theriol. 39: 103-107.

The summer food of the sable Martes zibellina Linnaeus, 1758, inhabiting taiga forests near Mirnoe Field Station on Middle Yenisei, Siberia, was studied by the analysis of 136 scats. Microtinae rodents (mainly northern red-backed vole Clethrionomys rutilus) constituted $52.3 \%$ of biomass consumed by sables. Plant food (seeds of Siberian pine Pinus sibirica and berries of Vaccinium sp.) was also frequently eaten; they occurred in $79.4 \%$ of scats but constituted only $19.9 \%$ of biomass. Shrews, burunduks Eutamias sibiricus, birds and insects were supplementary food, however, these groups of prey formed totally about $25 \%$ of consumed biomass.

Department of Ecology, University of Warsaw, Krakowskie Przedmieście 26/28, 00-927 Warsaw, Poland
\end{abstract}

Key words: Martes zibellina, diet, Siberia

\section{Introduction}

Sable Martes zibellina Linnaeus, 1758 is the mustelid species which, due to its valuable pelt, has inspired human interest for centuries (Numerov 1963). The numerous studies done by Russian biologists showed that: (1) sable is an opportunistic predator feeding on many kinds of prey, (2) the diet of sable in its wide geographic range varies considerably (Nadeev 1967, Nasimovič and Timofeev 1973, Sokolov 1978, Monahov and Bakeev 1981). This paper presents the data on sable diet, collected during the expedition to Siberia in summer 1992.

\section{Study area, material and methods}

Sable scats were collected in August 1992 on the right bank of Yenisei River, on the area of about $150 \mathrm{~km}^{2}$, in the neighbourhood of the Northern Ecological Station Mirnoe of the Institute of Evolutionary Morphology and Ecology of Animals, Russian Academy of Sciences $\left(62^{\circ} 20^{\prime} \mathrm{N}, 89^{\circ} 00^{\prime} \mathrm{E}\right)$. The taiga forests around the station have been exposed to human activity but more distant parts of the forest remained unaffected by man. Tree stands are dominated by: Pinus sibirica, Picea obovata, Betula alba, Populus tremula, Larix sibirica, Pinus silvestris and Abies sibirica. In this part of Siberia the mean temperature in June is 14 to $17^{\circ} \mathrm{C}$. Snow usually melts in April/May. 
Altogether, 136 scats were found from June to August. The excrements were washed through the sieve and dried (Lockie 1959). The identification of food remains was based on seeds, rodent and shrew skeletons, teeth and hair, that I collected in the study area during the expedition. The food composition was presented as (1) percentage occurrence of an item in the whole sample of scats and (2) percentage biomass of an item in the total biomass consumed per one scat. The consumed biomass was estimated using following correction factors: shrews and rodents -23 , birds -35 (Goszczyński 1974 for Vulpes vulpes), amphibians and reptiles - 18 (Fairley et al. 1987 for Mustela vison), insects - 5, fruits - 14 (Lockie 1961 for Martes martes). I assumed the correction factor of pine seeds to be 2, because the weight of shells (a defecated part of consumed seeds) constitutes about $50 \%$ of seed total weight. Despite the fact that correction factors were calculated for other pradators than the sable, it seems that percentage biomass method gives more accurate view of the real contribution of particular food items to the sable diet than the percentage occurrence method.

\section{Results}

Microtines were the most important component of the sable diet, they made $52.3 \%$ of consumed biomass (Table 1). Clethrionomys rutilus was the most frequently eaten rodent (33.1\% of occurrence). The only food item which was found in the sable scats more often than voles were seeds of Pinus sibirica $-66.2 \%$ of occurrence. However, the seeds composed only $10.3 \%$ of the total biomass. Similarly, Vaccinium sp. berries which occurred in $29.4 \%$ of the samples made a small part of the eaten biomass (7.4\%). Altogether, plant material was recorded in $79.4 \%$ of scats and was an important supplement (19.9\% of biomass) to the main food. The remains of shrews were found nearly in $30 \%$ of scats. Burunduks Eutamias sibiricus and birds occurred in the sable diet more rarely than shrews (both $8.1 \%$ ) but the contribution of these 3 items to the consumed biomass was comparable (9.3\%, 5.0\% and 9.3\%, respectively). Other small mammals (Sicista betulina, Sciurus vulgaris, Talpa altaica), frogs and lizzards were eaten by sables only ocasionally. Sables fed on wasps, probably digging up their nests. However, despite of considerable percentage occurrence in scats $(22.8 \%)$, insects due to their very small biomass seem to be unimportant food.

\section{Discussion}

In general, small rodents, Vaccinium sp. berries and seeds of Siberian pine dominate sable diet all over its geographic range (Abramov 1967, Nadeev 1967, Nasimovič and Timofeev 1973, Monahov and Bakeev 1981). Besides these food items, the sable feeds on many other plants and animals, thus it is commonly classified as a generalist predator (Tavrovskii and Šitarev 1957, Abramov 1967, Nasimovič and Timofeev 1973, Sokolov 1978, Monahov and Bakeev 1981). Both seasonal and long term changes in the sable diet resulting from the fluctuations of prey abundance were reported by Lavov (1959), Romanov (1959), Zaleker and Poluzadov (1959), Abramov (1967), Nadeev (1967), and Nasimovič and Timofeev (1981). 
Table 1. Diet composition of the sable Martes zibellina in summer (June - August) 1992, in taiga forests on Yenisei river, Siberia. $n=136$ scats, \% Occurrence - per cent scats containing a given item, $\%$ Biomass - per cent of total biomass consumed per 1 scat.

\begin{tabular}{|c|c|c|}
\hline Prey item & $\%$ Occurrence & $\%$ Biomass \\
\hline Pinus sibirica & 66.2 & 10.3 \\
\hline Vaccinium myrtillus & 7.4 & - \\
\hline Vaccinium vitis-idaea & 5.1 & - \\
\hline Vaccinium sp. & 16.9 & - \\
\hline Vaccinium - subtotal & 29.4 & 7.4 \\
\hline Rubus sp. & 0.7 & - \\
\hline Ribes sp. & 1.5 & - \\
\hline Undetermined plants & 2.9 & - \\
\hline Plant material - subtotal & 79.4 & 19.9 \\
\hline Clethrionomys rutilus & 33.1 & 33.3 \\
\hline Clethrionomys rufocanus & 2.9 & 4.9 \\
\hline Clethrionomys sp. & 14.7 & 7.6 \\
\hline Clethrionomys - subtotal & 49.3 & 45.8 \\
\hline Microtus oeconomus & 2.9 & - \\
\hline Undetermined Microtinae & 1.5 & - \\
\hline Microtinae - subtotal & 53.7 & 52.3 \\
\hline Eutamias sibiricus & 8.1 & 9.3 \\
\hline Sicista betulina & 0.7 & 0.4 \\
\hline Sciurus vulgaris & 0.7 & 0.9 \\
\hline Sorex caecutiens & 7.4 & - \\
\hline Sorex araneus & 2.2 & - \\
\hline Sorex isodon & 6.6 & - \\
\hline Sorex sp. & 13.2 & - \\
\hline Sorex - subtotal & 29.4 & 9.3 \\
\hline Talpa altaica & 0.7 & - \\
\hline Insectivora - subtotal & 30.1 & 10.0 \\
\hline Birds & 8.1 & 5.0 \\
\hline Bird eggs & 3.7 & - \\
\hline Rana chensinensis & 0.7 & - \\
\hline Rana sp. & 2.9 & - \\
\hline Anura-subtotal & 3.7 & 0.6 \\
\hline Lacerta vivipara & 1.5 & 0.5 \\
\hline Vespidae & 19.1 & 1.0 \\
\hline Carabidae & 1.5 & - \\
\hline Undetermined Insecta & 2.2 & - \\
\hline Insecta - subtotal & 22.8 & 1.1 \\
\hline Mean biomass per 1 scat $(\mathrm{g})$ & & 7.3 \\
\hline
\end{tabular}

The results from Mirnoe are comparable to the former data on the sable diet obtained in northern forests of Yenisei river region (see Monahov and Bakeev 1981) and nearby Tunguska river region (see Romanov 1959, Petrov 1979). The frequency of small rodent remains found in the sable scats was moderate, but the 
total biomass of consumed microtines exceeded the biomass of any other group of prey. The dominance of $C$. rutilus reflects its abundance in the studied area (B. Sheftel, unpubl.). Alike, Tavrovskii and Sitarev (1957) found that the high proportion of $C$. rutilus in the sable diet was due to its numbers in the rodent community.

Larger rodents (Eutamias sibiricus and Sciurus vulgaris) were very rarely found to be a dominant prey and their occurrence in scats usually did not exceed 10\% (Timofeev 1948, Lavov 1959, Černikin 1970, Makovkin 1979). Alike birds, shrews and insects were in most studies the secondary food of the sable (review in Nasimovič and Timofeev 1973, Monahov and Bakeev 1981). However, in some regions (as in winter in West Siberia) birds may compose up to $80 \%$ of the eaten prey (Monahov and Bakeev 1981). In the diet of sables from Mirnoe all these groups of prey constituted supplementary food.

I recorded fairly high contribution of insectivores to the sable diet. Former data from many parts of Siberia showed much lower consumption of shrews by the sable, their contribution usually did not exceed $10 \%$ (review in Monahov and Bakeev 1981). The reason, why shrews are avoided by mammalian carnivores is probably their bad taste (Korpimäki and Norrdahl 1989). In Mirnoe, shrew species found in the sable scats dominated in the community of insectivores and densities of two shrew species: Sorex caecutiens and $S$. araneus were comparable to densities of $C$. rutilus (B. Sheftel, unpubl.).

Many authors point out the importance of plants, especially pine seeds, in the sable diet (review in Monahov and Bakeev 1981). Nasimovič and Timofeev (1973) sugest that pine seeds are so important to sable that the geographic range of this predator is related to the range of Siberian pine. Pine seeds were indeed commonly eaten by sables in Mirnoe. Seed abundance in early summer is usually the lowest, thus the consumption of this plant food by sables decreases comparing to other seasons (Černikin 1970). However, in several regions of Siberia, the occurrence of pine seed remains in sable scats may reach in summer about $50 \%$ (review in Monahov and Bakeev 1981). Pine seeds are highly energetic food but they are poorly digestible thus, the percentage occurrence method may often overestimate the real importance of this food item for sables. In summer seeds and fruits may be an important supplement to the sable diet but it is unlikely that they may become the basic food.

In this season sables have wider food spectrum than in other months of the year (Timofeev 1948, Abramov 1967, Makovkin 1979). Besides rodents, which are the main prey, also fruit, birds, eggs, nestlings, amphibians and insects are easily available. The sable generalistic feeding habits seem to be an important ability of an animal living in habitats of variable levels of food resources (Raevskii 1947, Timofeev 1948, Abramov 1967).

Acknowledgements: I am very grateful to Dr B. Sheftel for data on the rodent and insectivore densities in the study area. My thanks are also due to him and all other persons from Mirnoe Field Station who helped me to collect the comparative material of mammalian species. I thank Dr B. Jędrzejewska for comments on the manuscript and improving the English. 


\section{References}

Abramov K. G. 1967. Pitanie sobolja. [In: Sable in the hunting of the Far East. K. G. Abramov, ed]. Publishing House "Nauka", Moscow: 59-64. [In Russian]

Černikin E. M. 1970. Materialy po ekologii barguzinskogo sobolja. Trudy/Barguzinskii gos. Zapovednik, Ulan-Ude, 6. [In Russian]

Fairley J. S., Ward D. P. and Small C. M. 1987. Correction factors and mink faeces. Ir. Nat. J. 22: 334-336.

Goszczyński J. 1974. Studies on the food of foxes. Acta theriol. 19: 1-18.

Korpimäki E. and Norrdahl K. 1989. Avian and mammalian predators of shrews in Europe: regional differences, between-year and seasonal variation, and mortality due to predation. Ann. zool. Fenn. 26: $389-400$.

Lavov M. A. 1959. Influence of sable on squirrel population in Transbaikalia. Zool. Ž. 38: 261-267. [In Russian with English summary]

Lockie J. D. 1959. The estimation of the food of foxes. J. Wildl. Manage. 23: 224-227.

Lockie J. D. 1961. The food of pine marten Martes martes in West Ross-Shire, Scotland. Proc. zool. Soc. Lond. 136: 187-195.

Makovkin L. I. 1979. K pitaniju sobolja na juge Primorja. [In: Ekolologičskie osnovy ohrany i racionalnogo ispolzovanija hiščnyh mlekopitajuščih]. Izdatelstvo "Nauka", Moskva: 284-286. [In Russian]

Monahov G. I. and Bakeev N. N. 1981. Obraz žizni. Ekologičeskii očerk. Pitanie. [In: Sobol. G. I. Monahov and N. N. Bakeev, eds]. Lesnaja promyšlennost', Moskva: 126-147. [In Russian]

Nadeev V. N. 1967. Geografičeskie osobennosti v pitanii sobolja (Martes zibellina L.) Zapadnoi i Srednei Sibiri. Tr. Vses. n. issled. In-ta. Syrja i Pušniny 21: 34-47. [In Russian]

Nasimovič A. A. and Timofeev V. V. 1973. Sobol. Geografičeskie osobennosti pitanija. [In: Sobol, kunicy, harza. A. A. Nasimovič, ed] Izdatelstvo "Nauka", Moskva: 32-35. [In Russian]

Numerov K. D. 1963. The past and the present of the ermine in the north of Enisseyan Siberia. Zool. Z . 42: 1088-1097. [In Russian with English summary]

Petrov B. I. 1979. Pitanie i razmnoženie tungusskogo sobolja. [In: Ekologičeskie osnovy ohrany i racionalnogo ispolzovanija hiščnyh mlekopitajuščih]. Izdatelstvo "Nauka", Moskva: 288-289. [In Russian]

Raevskii V. V. 1947. Žizn kondo-sosvinskogo sobolja. Glavnoe upravlenie po zapovednikam pri SM RSFSR. Moskva. [In Russian]

Romanov I. V. 1959. Dependence of sable helminthofauna in Krasnoyarsk Territory on the external medium of this animal. Zool. Ž. 38: 1313-1321. [In Russian with English summary]

Sokolov G. A. 1978. Vnutripopuljacionnje različija trofičeskih svjazei u sobolja. [In: Ekologija pitanija lesnyh životnyh. D. V. Vlabyševskii, ed]. Izdatelstvo "Nauka", Novosibirsk: 50-57. [In Russian]

Tavrovskii V. A. and Šitarev I. S. 1957. Material on the feeding habits of the sable in north-western Yakutia. Zool. Ž. 36: 608-616. [In Russian with English summary]

Timofeev V. K. 1948. Ekologija barguzinskogo sobolja - Martes zibellina princeps Birula. Trudy Barguzinskogo gos. Zapovednika 1: 1-101. [In Russian]

Zaleker V. L. and Poluzadov N. B. 1959. Kormovoi režim i plodovitost' sobolei Zauralja. Tr. Vses. n. issled. In-ta. Syrja i Pušniny 18: 18-27. [In Russian]

Received 13 August 1993, accepted 5 February 1994. 